\title{
Analysis of involvement of women in seed systems in Borno State, North- East Nigeria
}

\author{
${ }^{1 *}$ Bawa, D.B, ${ }^{2}$ Donye, A.O. and Nuhu, ${ }^{1}$ H.S, \\ ${ }^{1 *}$ Department of Agricultural Economics and Extension Services, University of Maiduguri. \\ ${ }^{2}$ Department of Agricultural Economics and Extension \\ Adamawa State University, Mubi. \\ Corresponding Authour: bawad3@yahoo.com, dauda71bawa@gmail.com
}

Tel: (+234) 803-439-0119

\begin{abstract}
The study was on the involvement of women in seed systems in Hawul Local Government Area of Borno State, Nigeria. Multistage probability sampling procedure was employed in the selection of the respondents. In the first stage, four (4) districts were selected. In the next stage, one (1) village was randomly selected from each of the selected districts. Subsequently, twenty five (25) respondents were randomly selected from each of the selected villages, which brought the total number of the respondents to one hundred (100). A structured interview schedule was used in collecting data from the respondents. Data were analyzed using descriptive and inferential statistics. The descriptive tools used were frequencies and percentages, while the inferential tool used was multiple regressions analysis. The major findings of the study were that majority of the respondents were involved in seed systems; age, education and farming experience were significantly related with involvement of women in seed systems at $1 \%$ and $5 \%$ levels of significance and contributed $58 \%, 30 \%$ and $10 \%$ respectively, with $R^{2}$ value of 0.657 . It was suggested, among others, that if government at various levels, agricultural extension programmes and other agriculture related agencies embark on organizing educational programmes, providing the respondents with capital, storage facilities and policies that will lead to the expansion of their farm sizes, these could enhance and improve their productivity and performance in seed systems.
\end{abstract}

\section{Keywords: Involvement, Women, Seed Systems, INTRODUCTION}

Seed is one of the most important inputs in all crop based agriculture and a pre-requisite for the majority of the world's food production. It provides the basis for crop improvement allowing farmers and plant breeders to develop cultivars with high level of adaptation (Badstue, 2006). Seed, in the context of most farmers, refers to any plant part which reproduces the same kind of seed or crop. It is a primary agricultural input and is the embodiment of the farmer's future harvest and productivity (Musa, 1996). "Farmers' seed production" essentially refers to growing a crop of which part is saved as seed for own use. Saving the best grains, roots or tubers from consumption, their storage and planting developed over centuries. This aspect of seed selection is part of what is known as "seed system", which basically involves seed production carried out by farmers. All these are referred to as "farmer seed systems" or "local seed systems" (Musa, 1996).
Farmers that are involved in seed system are not only men, but women form a very large integral part of the agricultural activity (Giwa, 2000; Witchterich, 1985; Saito et al., 1994). Women today have widely engaged in agricultural production, especially crop production such that culturally, food crop production and processing is to be a woman's job. In other words, seed supply system has traditionally been associated with women in the informal farmer seed system. Women, over the centuries, have developed an intrinsic ability to select the correct mix of the crops and varieties to meet the farmers' expectations. Since the required quantities of seed for producing most crops is relatively small, women have generally developed the knowledge and skills associated with the conditioning, processing and storage of such seed (Musa, 1996).

In view of the aforementioned contribution of women in agricultural production, the main objective of this study is to examine the involvement of women in seed system in Hawul local government area of 
Borno State Nigeria. The specific objectives are to: (i) identify the socio-economic characteristics of the respondents; (ii) investigate the accessibility of the respondents to credit facilities (iii) investigate the respondents' accessibility to agricultural extension services; (iv) examine the involvement of women in seed systems. In addition to these, one hypothesis was developed and tested, namely: (i) there is no significant relationship between the socio-economic characteristics of the respondents and their level of involvement in seed systems.

\section{METHODOLOGY}

The study was carried out in Hawul Local Government Area of Borno State, Nigeria. The local government area, which is predominantly comprised of farmers, is located between latitude $10^{\circ} \mathrm{N} 51^{\circ} \mathrm{E}$ and longitude $12^{\circ} \mathrm{N} 35^{\circ} \mathrm{E}$ of the equator (Ministry of Land and Survey 2007). The estimated population is 120,314 of which 59,995 were men, while 60,319 were women (National Population Commission, 2006).

Multistage random sampling procedure was employed in the selection of the respondents. In the first stage, four (4) districts were selected. In the second stage, one (1) village was randomly selected from each district. Subsequently, twenty five (25) respondents were selected from each of the selected villages, which brought the total number of respondents to one hundred (100). Descriptive (percentages and frequencies) and inferential (multiple linear regression model) statistical tools were employed to analyze the data.

$Y=\alpha+\beta_{0}+\beta_{1} X_{1}+\beta_{2} X_{2}+\beta_{3} X_{3} \ldots \ldots \ldots \ldots \beta_{n} X_{n}+\varepsilon$

Where $Y=$ dependent variable (involvement of women in seed system)

$\alpha, \beta_{1}, \beta_{2}, \beta_{3} \ldots \ldots \ldots \ldots \beta_{n}$ are coeffient

$\beta_{0}=$ constant

$X_{1 \ldots \ldots \ldots \ldots \ldots \ldots \ldots} X_{n}$ are independent variables

$\mathrm{e}=$ ramdom error

$\mathrm{X}_{1}=$ Age

$X_{2}=$ Marital status

$\mathrm{X}_{3}=$ Family size

$\mathrm{X}_{4}=$ Education

$\mathrm{X}_{5}=$ Farming experience

$\mathrm{X}_{6}=$ Primary occupation

$\mathrm{X}_{7}=$ Secondary occupation

$\varepsilon=$ Random error

\section{RESULTS AND DISCUSSION}

Table 1 show that the age group of the respondents with the highest percentage $(32 \%)$ is within the age range of 35-45 years. The age range of 25-35 years constituted $26 \%$ and that of $18-25$ years was $25 \%$. Thus, when summed up, $83 \%$ are within the age range of 18-45 years all of which were agile, active and dedicated women. These groups of individuals are able bodied and highly productive. This accounts for their involvement in seed systems and by this they became self-employed in order to provide themselves better living conditions. This finding is supported by the findings of Ogunbameru (2001), which stated that young and middle aged people are active in agricultural production activities and have increased productivity. Because of their active nature, they spend much of their time on the farm. This is also consistent with the report that women laboured between 15-20 hours a day, growing $80 \%$ of African food and, hence, ensuring the health, education and overall well being of families and communities (African farmer, 1994).

Table 1 revealed that about $40 \%$ had post primary education qualification followed by $17 \%$ who had adult education qualification, and $15 \%$ with primary education qualification. Only 19\% had tertiary education qualification. Based on these findings, it could be said that the various levels of education of the respondents did enhance their understanding of innovations and information that extension agents pass across to them. This had also increased their willingness for adopting given technologies. This position goes in line with the findings of Ogunbameru (2001), and Omoteso and Olawale (1991) who all observed that educated farmers can get information from a wide range of sources, such as extension agents, electronic print media and internet, and also use their abilities to secure necessary inputs such as credit, fertilizers and improved seeds for continuous production. They also reported that minimum level of education helps extension agents to find it easier to operate successfully, because minimum educational qualification is necessary for farmers to understand scientific and technical rationale of modern agriculture.

Access to Agricultural Extension Services: Table 2 shows the distribution of the respondents' access to the services of extension agents in their localities. The table shows that $92 \%$ of the respondents are of the view that extension agents are present in the locality, while $8 \%$ disagree. This shows, anyway, that the presence of extension agents in the area of study is highly acknowledged by the majority of the 
respondents. However, it could be that despite the presence of the extension agents, issues discussed by them may not be on agricultural production. This assertion is supported by the World Bank report which indicated that most extension messages targeted at women emphasized the domestic role with topics on child care and family nutrition (World Bank, 1989).

Table 1: Socio-Economic Characteristics of the Respondents ( $\mathrm{N}=\mathbf{1 0 0})$

\begin{tabular}{|c|c|c|}
\hline Age (Years) & Frequency & Percentage \\
\hline $18-25$ & 25 & 25 \\
\hline $25-35$ & 26 & 26 \\
\hline $39-45$ & 32 & 32 \\
\hline $45-55$ & 15 & 15 \\
\hline$>55$ & 2 & 2 \\
\hline Total & 100 & 100 \\
\hline \multicolumn{3}{|l|}{ Marital Status } \\
\hline Married & 76 & 76 \\
\hline Single & 18 & 18 \\
\hline Divorced & 5 & 5 \\
\hline Widowed & 1 & 1 \\
\hline Total & 100 & 100 \\
\hline \multicolumn{3}{|l|}{ Family Size } \\
\hline Children & 21 & 21 \\
\hline $1-4$ children & 48 & 48 \\
\hline $5-8$ children & 28 & 28 \\
\hline Above 8 children & 3 & 3 \\
\hline Total & 100 & 100 \\
\hline \multicolumn{3}{|l|}{$\begin{array}{l}\text { Educational } \\
\text { Qualification }\end{array}$} \\
\hline Adult education & 17 & 17 \\
\hline Primary education & 15 & 15 \\
\hline Post primary education & 40 & 40 \\
\hline Tertiary institution & 19 & 19 \\
\hline Qu'ranic education & 8 & 8 \\
\hline None & 1 & 1 \\
\hline Total & 100 & 100 \\
\hline \multicolumn{3}{|l|}{$\begin{array}{ll}\text { Farming } & \text { Experience } \\
\text { (Years) } & \end{array}$} \\
\hline$<1$ & 1 & 1 \\
\hline $2-3$ & 5 & 5 \\
\hline $4-5$ & 18 & 18 \\
\hline$>5$ & 76 & 76 \\
\hline Total & 100 & 100 \\
\hline $\begin{array}{l}\text { Source: Field survey, } \\
2009\end{array}$ & & \\
\hline
\end{tabular}

More so, it could be that they do not even give time to the women at all as found out by the SPORE, (1993) which disclosed that, not only do products tend to be oriented towards crops traditionally grown by men but the training given it is also aimed at men. Ani(2002), also stated that, built into the structure of the agricultural extension system is sex-segregated division of labour under which male extension workers deliver technical knowledge to male children, as though rural women have little part to play in agricultural production. Similarly, Dey (1984), reported that a study in Tsito, a village in southern Ghana, showed that until 1977, none of the women interviewed has ever been visited on their farms by extension officers.

The results presented on the table also show that $96 \%$ of the respondents indicated that most of the extension agents are males. This did not auger well for the extension agents because in some cultures and religious institutions, contact for any purpose is not allowed between men and women. However, there is now increased pressure on extension and research services to focus more effectively on the tasks performed by women. Practical solutions are difficult to identify and even more difficult to implement. For example, the common proposal to have more male extension staff is not necessarily an answer if female employees are constrained from traveling freely to farmers or if suitable technologies for the tasks performed by women farmers are not available (Nigel, 1980). In view of the orientation of most extension and research services, the composition of their staff and their poor track record in helping women, the task of developing effective extension for women farmers will not be easy.

The existing programmes have failed to take into consideration the socio-cultural constraints faced by women. Few extension services are targeted at rural women, few for commercial rather than subsistence crop production which is the primary concern of women (Boserup, 1970).

Accessibility of the Respondents to Credit Facilities: Table 3 shows a record of $76 \%$ of the respondents having no access to financial aids, while only $24 \%$ do. This is in line with the finding of Youssef (1995), in which he indicated that steps taken to make credit available to the poor have mostly benefited only male counterparts, leaving the poor women with little access to financial markets, both because they are poor and that they are women. 
Table 2: Respondents' Access to Extension Service Delivery $(\mathrm{N}=100)$

\begin{tabular}{|l|c|c|}
\hline Variables Percentage & \multicolumn{2}{|c|}{} \\
\hline Presence of Extension Agents & Frequency & $\begin{array}{c}\text { Percenta } \\
\text { ge }\end{array}$ \\
\hline Yes & 92 & 92 \\
\hline No & 8 & 8 \\
\hline Total & $\mathbf{1 0 0}$ & $\mathbf{1 0 0}$ \\
\hline & & \\
\hline Gender of Extension Agent & & \\
\hline Male & 96 & 96 \\
\hline Female & 4 & 4 \\
\hline Total & $\mathbf{1 0 0}$ & $\mathbf{1 0 0}$ \\
\hline
\end{tabular}

Source: Field Survey, 2009

The table shows that $88 \%$ of the respondents do not have access to bank loans, while only $12 \%$ have access to it. This shows that Nigerian banks are not playing an important role in the assistance expected by the respondents. Majority $(72 \%)$ of the respondents do not get access to bank loan because of their inability to produce or tender collateral. Food and Agriculture Organization (FAO) (1990) reported that in an analysis of credit schemes in five (5) African countries where women predominate in food production, it was found that women received less than $10 \%$ of the total credit directed to agriculture as a result, in part, of their lack of collateral required to guarantee loans. Moreover, since they have few assets, they cannot provide the collateral required by lending institutions (Kleyson, 1996). While for cooperatives, SPORE (1993) reported that in some villages where cooperative credit systems exist, often only the men constitute the memberships.

Effort was also made to find out if there were any relationships between the involvement of women in seed systems and their socio-economic characteristics (age, marital status, family size, education, farming experience, primary occupation and secondary occupation) studied. The results Table 4 showed that age was significantly related (at $1 \%$ level) with the respondents' involvement (58\%) in seed systems. This agrees with the findings of Ogunbameru, (2001) and Ani and Kwaghe, (1997) who all reported that young and middle aged people are most active in agricultural production activities for increased productivity. Similarly, at $1 \%$ level of significance, educational qualification was found to be significantly related. Under this independent variable, $30 \%$ of the respondents were involved. This result is in agreement with the finding of Ani, (2004) in which he reported that high level of education will translate into economic progress and that education has been variously described as a powerful instrument for attaining the much desired objectives of economic progress, rural development and total emancipation of the entire human race.

Farming experience was also found to be significantly related (at $5 \%$ level of significance) with the respondents' involvement in seed systems. This is in line with the finding reported by Ani and Donye (2005), in which they indicated that there is a strong association between farming experience and the yield obtained by vegetable farmers. This positive achievement may not be unconnected with the accumulation of farming knowledge over the years by the respondents, which gives them more farming technical know-how by the year.

However, family size was found to be not significant. This could be attributed to the fact that in a family of many or few household members each may have his own priorities differently from those of others. For instance, in a family size of ten members, only one may be interested in farming as a business not even to talk of seed systems enterprise involvement.

Table 3: Distribution of Respondents Based on Accessibility to Credit Facilities ( $N=100)$

\begin{tabular}{|c|c|c|}
\hline Variables & Frequency & Percentage \\
\hline \multicolumn{3}{|l|}{ Access to Financial Aids } \\
\hline Yes & 24 & 24 \\
\hline No & 76 & 76 \\
\hline Total & 100 & 100 \\
\hline \multicolumn{3}{|l|}{ Source of Loan } \\
\hline Bank & 9 & 9 \\
\hline Cooperatives & 11 & 11 \\
\hline \multicolumn{3}{|l|}{ Borrowing from friends } \\
\hline or relatives & 77 & 77 \\
\hline $\begin{array}{lll}\begin{array}{l}\text { Borrowing } \\
\text { collectors }\end{array} & \text { from } & \text { thrift } \\
& & \end{array}$ & 3 & 3 \\
\hline Total & 100 & 100 \\
\hline \multicolumn{3}{|l|}{ Access to Bank Loan } \\
\hline Yes & 12 & 12 \\
\hline No & 88 & 88 \\
\hline Total & 100 & 100 \\
\hline \multicolumn{3}{|l|}{ If No, Why? } \\
\hline No collateral to tender & 72 & 72 \\
\hline No farm record & 15 & 15 \\
\hline Loan requested too small & 2 & 2 \\
\hline No guarantor to stand & 11 & 11 \\
\hline Total & 100 & 100 \\
\hline \multicolumn{3}{|l|}{ 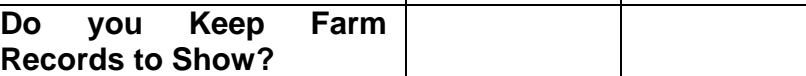 } \\
\hline Yes & 35 & 35 \\
\hline No & 65 & 65 \\
\hline Total & 100 & 100 \\
\hline
\end{tabular}

Source: Field Survey, 2009 
Table 4: Regression Analysis on the involvement of women in seed systems

\begin{tabular}{|c|c|c|c|}
\hline Variables & Coefficient & t-ratio & $\begin{array}{l}\text { Signif- } \\
\text { icance }\end{array}$ \\
\hline Age & $.0137^{* *}$ & 1.923 & .058 \\
\hline Marital status & $.338^{* * *}$ & 5.005 & .000 \\
\hline Family size & $.0437^{\mathrm{NS}}$ & 1.113 & .269 \\
\hline Education & $.0256^{\star *}$ & 2.177 & .032 \\
\hline Farming Experience & $.156^{\star * *}$ & 2.996 & .004 \\
\hline Primary occupation & $.159^{\star \star *}$ & 3.190 & .002 \\
\hline $\begin{array}{l}\text { Secondary } \\
\text { occupation }\end{array}$ & $.134^{* * *}$ & 2.739 & .007 \\
\hline Constant & .107 & .459 & .647 \\
\hline$R^{2}=0.657$ & & & \\
\hline
\end{tabular}

${ }^{* \star}$ Significant at $5 \%$

*** Significant at $1 \%$

\section{CONCLUSION}

This study was on the involvement of women in seed systems in Hawul Local Government Area of Borno State, Nigeria. The intention of the study was to intimate researchers, research institutes, agricultural development agencies and policy makers with not only the degree of involvement of women in seed systems, but also to explore the factors that influence their involvement.

It was indicated in the study that majority of the respondents were involved in seed systems. Results of the study showed that the activities were carried out on small-scale levels and farm sizes. This is a serious problem to the respondents which greatly inhibits the use of the whole of their potentials in seed systems.

The subsistent levels of operations by the women were attributed to their low educational levels and lack of capital. This is because the study showed that there were strong significant relationships between their socio-economic characteristics and their involvement in seed systems. Therefore, organizing educational programmes and formulation of agricultural policies that are favourable to seed systems and other agricultural activities will not only improve their levels of performance, but could also enhance their standard of living. This could subsequently guarantee the conservation of seed genetic characteristics, easy access to seed and seed availability.

\section{REFERENCES}

African Farmer (1994): Given Women a Place at the Policy Table, the Hunger-Project, New York, April Quarterly Publication, P. B

Ani, A. O. (2002): Factors Attributing Agricultural Production among Rural Women in Southern Ebonyi State, Nigeria. Unpublished Ph. D. Thesis Submitted to the Department of Sociology and Anthropology, University of Maiduguri.

Ani, A. O. (2004): Women in Agriculture and Rural Development. Priscaquila, Maiduguri.

Ani A.o and A. O. Donye (2005). Irrigated Vegetable Production Among Small-scale Farmers in Lamurde of Agamawa State, Nigeria. International Journal of Food and Agriculture, Vol. 2 No. $1 \& 2$

Ani, A. O. and Kwaghe, P. V. (1997). Source of Information of Improved Farm Practices: A Study of Farmers in Umuahia Zone of Abia State, Nigeria, AGROSEARCH: A Journal of Agriculture, Food and Development, Vol. 3, (1\&2): 1-9.

Badstue, L. B. (2006): Small-holder seed practices: Maize seed management in the central valleys of Oaxaca, Mexico, Ph. D. thesis, Wayeningen University, Wageninger, and the Netherlands.

Borno State Agricultural Development Programme, BOSADP (2001)

Borno State Ministry of Land and Survey (2007): Geographical Location of Borno State.

Boserup, P. E. (1970): Agricultural Development Strategies in Nigeria: past present and future, Nigeria outlook workshop held at Kaduna on 8th January, 1987 at Durba Hotel.

FAO (1990), Women in agriculture development. FAO women, food systems and agriculture. FAQ, Rome, Italy.

Giwa G. (2000): The role of women in processing and marketing of sweet potatoes in Offa Local Government Area, Kwara State B. Sc. Project. Department of Agricultural Economics and Extension, University of Maiduguri.

Kleyson, B. (1996): Women Small Farmers in the Caribbean. Programme for the Analysis of Agricultural Policies Vis-à-vis. Women Food Produces in the Andean Region, the Southern Cone and the Caribbean July 1996. 1DB: 11CA, p. 232

Musa, T. M. (1996). Pilot Project Sorghum and Pearl Millet Seed Production in Ward 21 of Chivi, Zimbabwe. SADC/GTZ project in small scale seed production by self-help groups. Harare, I2pp.

Nigel, R. (1980): Agricultural Extension in Africa. A World Bank Symposium Oxford University Press. 
Agric. Biol. J. N. Am., 2010, 1(6): 1237-1242

National Population Commission of Borno State (NPC). (2006) Census.

Ogunbameru, B. O. (2001): Practical Agriculture Communication, Published by Daily Graphics Ibadan.

Omoteso, O. A. and Olawale, A. (1991). Economics of Dry Season Vegetable Production Along Asa River Bank, In: A. O. Ani and A. O. Donye. Irrigated Vegetable Production Among Small-scale Farmers in Lamurde of Adamawa State, Nigeria.

PROSAB (2006). Mid term evaluation final report, June 2006. Canadian International Development Agua.

Saito, K., H. Mekonnen, and Spurling, D. (1994). Raising the productivity of women farmers in sub-saharan
Africa, World Bank. Discussion paper, Washington D.C.

SPORE, (1993): A Woman's Rightful, Place Bi-monthly of the Technical Centre for Agricultural and Rural Cooperation (CTA), the Netherlands.

Witchterich, C. (1985). Another development with the other sex. Development and Co-operation, 6:11-12.

World Bank, (1989): Designing and Implement Agricultural Extension for Women Farmers. World Bank Discussion Paper. 103, Washington, D. C.

Youssef, N. H. (1995): Women Access to Productive Resource: the Need for Legal Instrument to Protect Women's Development Right, Rout Ledge, New York, PP. 279-289. 